\title{
Ashed SBE Adsorbent for Lead and Zinc (II) Ions: Kinetic and Equilibrium Studies
}

\author{
Genson Murithi ${ }^{1}$, Karanja wa-Thiong'o ${ }^{2}$, Wachira Muthengia ${ }^{3}$ \\ ${ }^{1}$ Department of Chemistry, Kenyatta University, P.O. Box, 43844-00100, NAIROBI, KENYA \\ ${ }^{2}$ Department of Chemistry, Kenyatta University, P.O. Box, 43844-00100, NAIROBI, KENYA \\ ${ }^{3}$ Department of Physical Sciences, Embu University College, P.O. BOX 6-60100, EMBU, KENYA
}

\begin{abstract}
The present study investigated the adsorption potential of Ashed SBE(spent bleaching earth) to remove lead (II) and zinc (II) ions from industrial effluent. The effluent was found to have a higher percentage of lead (II) and zinc (II) ions beyond the acceptable WHO(World health organization) standards. The maximum adsorption capacity was found to be 29.8 and $43.4 \mathrm{mg} / \mathrm{L}$ for adsorption of lead (II) and zinc (II) ions respectively. Lead and zinc (II) ions removal was mainly influenced by the operating variables of the solid/liquid ratio and the $\mathrm{pH}$ of the aqueous phase. The kinetic data was evaluated and the pseudo-second-order equation provided the best correlation. The present study demonstrated that ASBE is a promising material that may be used for the removal of heavy metal ions from industrial effluents.
\end{abstract}

Keywords: Adsorption; Ashed SBE; Isotherms Kinetics, Lead (II) and Zinc (II) ions.

\section{Introduction}

The use of various adsorbents for the removal of heavy metal ions from aqueous solution is of great interest due to environmental concerns. Lead and zinc are widely used in many industrial applications. Lead is used battery cells, paints, manufacturing, printing pigments, and fuels among others [1]. Lead exposure causes weakness in fingers, wrists and ankles. The effects of lead toxicity are very wide and include impaired blood synthesis, hypertension, severe stomach ache, brain, kidney damage and even can cause miscarriage in pregnant women [2].Zinc is used in a variety of industrial products. For example, Zinc Oxide is used as a sunscreen agent. It reflects and scatters UV radiation. Sunscreen products reduce or prevent sunburn and premature aging of the skin. Preventing sunburn is an important factor in reducing the risk of getting skin cancer. Zinc citrate is used in toothpaste and mouthwash [3]. Excessive zinc intake suppresses copper and iron intake. This can lead to nausea, vomiting, pain, cramps and diarrhea may occur. There is also a condition called the "zinc shakes" or "zinc chills" or metal fume fever that can be induced by the inhalation of freshly formed zinc oxide formed during the welding of galvanized materials [4]. The removal of heavy metals from contaminated water bodies has been attempted by several scientists employing a wide variety of techniques. These include chemical precipitation, ion-exchange, electro flotation, membrane filtration, reverse osmosis and so on. All these methods are generally expensive. For this reason, there is a need to develop economic and eco-friendly methods for heavy metal ions removal. Currently SBE is dumped in open fields within operation areas of oil processing factories, in Kenya. There is need for investigation on its suitability as an adsorbent. Most of the research has been done used simulated water. It is important to use the real industrial wastewater. In this paper, we describe our efforts to remove lead (II) and zinc (II) ions from industrial effluent using ashed SBE. The adsorption of metal ions was investigated with variations in the parameters of $\mathrm{pH}$, contact time, initial metal ions concentration and temperature.

\section{Modelling and Analysis of Batch Data}

The equilibrium relationships between adsorbent and adsorbate are best explained by sorption isotherms [5]. They describe the relationship between the mass of the adsorbed component per biosorbent mass and the concentration of its component in solution. Determination of equilibrium parameters provides important information used in designing of adsorption systems [6]. The performance and the absorbent ability for absorbing the lead and zinc (II) ions aqueous solution were evaluated by Langmuir and Freundlich models. Temkin and Dubinin-Raduskevich were also used in providing information on the heat of adsorption and verifying results from Langmuir and Freundilich isotherms [7]. The Langmuir equation may be formulated as

$$
\mathrm{q}_{\mathrm{e}}=\frac{\mathrm{bQ}_{\mathrm{max}} \mathrm{C}_{\mathrm{eq}}}{1+\mathrm{bC}_{\mathrm{eq}}}
$$

Where $\mathrm{q}_{\mathrm{e}}$ corresponds to the amount of solute ions, $\mathrm{C}_{\mathrm{e}_{\mathrm{q}}}$ is the solute concentration in aqueous solution after equilibrium is reached, $\mathrm{Q}_{\max }$ represents practical limitation adsorption capacity, b is an affinity constant for binding sites. A high value of $\mathrm{b}$ indicates a high affinity of the biosorbent for the sorbate. The essential characteristics of the Langmuir equation can be expressed in terms of a separation factor $R_{L}$ which is a dimensionless constant given by equation 2 [8].

$$
\mathrm{R}_{\mathrm{L}}=\frac{1}{1+\mathrm{Q}_{\max } \mathrm{C}_{\mathrm{o}}}
$$

Freundlich is an empirical isotherm model that considers heterogeneous adsorption on the adsorbent surface and is given by equation 3 .

$$
\mathrm{q}_{\mathrm{e}}=\mathrm{K}_{\mathrm{f}} \mathrm{C}_{\mathrm{e}}^{\frac{1}{\mathrm{n}}}
$$




\section{International Journal of Science and Research (IJSR) \\ ISSN (Online): 2319-7064}

Index Copernicus Value (2013): 6.14 | Impact Factor (2014): 5.611

Temkin isotherm assumes that the heat of adsorption of all the molecules in the layer decreases linearly with coverage due to species-adsorbate interactions [9].The linearised equation is given by equation 4

$$
\mathrm{q}_{\mathrm{e}}=\mathrm{BLn}_{\mathrm{T}}+\mathrm{BLnC}_{\mathrm{e}}
$$

Where $A_{T}$ is Temkin isotherm equilibrium binding constant corresponding to the maximum binding energy, $\mathrm{b}_{\mathrm{T}}$ is Temkin isotherm constant, $\mathrm{R}$ is universal gas constant, $\mathrm{T}$ is the absolute temperature and $\mathrm{B}$ is Constant related to heat of sorption. The magnitude of $\mathrm{A}_{\mathrm{T}}$ provides guidance on selection of the adsorbent.

Dubinin-Radushkevich isotherm is generally applied to express the adsorption mechanism with a Gaussian energy distribution onto a heterogeneous surface. The model has often successfully fitted high solute activities and the intermediate range of concentrations data well [10]. The model is represented by equation 5 .

$$
\mathrm{q}_{\mathrm{e}}=\left(\mathrm{q}_{\mathrm{s}}\right) \exp \left(-\mathrm{K}_{\mathrm{ad}} \varepsilon^{2}\right)
$$

Where, $\mathrm{q}_{\mathrm{e}}$ is amount of adsorbate in the adsorbent at equilibrium, $\mathrm{q}_{\mathrm{s}}$ is theoretical isotherm saturation capacity, $\mathrm{K}_{\mathrm{ad}}$ is the Dubinin-Radushkevich isotherm constant and $\varepsilon$ is the Polanyi potential.

\section{Kinetics of Bisorption}

The adsorption kinetic studies describe the solute uptake rate which in turn controls the residence time of adsorbate uptake at the solid-liquid interface. Biosorption kinetics is described traditionally by the pseudo first order model of Lagergren or by pseudo second order kinetics. The linearised pseudo-first order is given by equation 6 .

$$
\log \left(q_{e}-q_{t}\right)=\log q_{e}-\frac{K_{L} t}{2.303}
$$

Where $K_{L}$, is the Lagergren constant, $q_{e}$ is the metal adsorbed at equilibrium, $\mathrm{q}_{\mathrm{t}}$ is the metal adsorbed at a given time and $t$ is the time taken for the adsorption to take place. The pseudo-second order equation is based on the assumption that the rate-limiting may be chemical adsorption [11]. Linearised pseudo - second order equation is given by equation 7.

$$
\frac{\mathrm{t}}{\mathrm{q}_{\mathrm{t}}}=\frac{1}{\mathrm{~K}^{\prime} \mathrm{q}_{\mathrm{e}}^{2}}+\frac{\mathrm{t}}{\mathrm{q}_{\mathrm{e}}}
$$

Where $K^{\prime}$ is the pseudo - second order rate constant of adsorption, $\mathrm{q}_{\mathrm{e}}$ is the metal adsorbed at equilibrium, $\mathrm{t}$ is the time taken for the adsorption to take place and $q_{t}$ is the metal adsorbed at a given time [12].

\section{Experimental}

\subsection{Industrial Effluent}

The industrial effluent was sampled into $100 \mathrm{ml}$ plastic bottles and two drops of $0.01 \mathrm{M}$ nitric acid were immediately added using a dropper. The effluents temperature and $\mathrm{pH}$ were determined on site. The color of the effluent was also noted on site. The samples were transferred to the laboratory and stored in a refrigerator. The effluent was subjected to COD, BOD and turbidity tests.

\subsection{Preparation of Adsorbent}

SBE was washed several with deionised water. It was ashed in the furnace at $850{ }^{\circ} \mathrm{C}$ for 5 hours. After cooling, it was placed in $0.01 \mathrm{M}$ nitric acid then rinsed with distilled water until a $\mathrm{pH}$ of $6.5-7$ was obtained. It was then mixed with 1 $\mathrm{M}$ potassium hydroxide in a bomb reactor for 24 hours. The resulting earth ash was then washed with distilled water to a $\mathrm{pH}$ of 6.5- 7. It was then oven dried at $80{ }^{\circ} \mathrm{C}$ for 5 hours and finally stored in plastic bottles. The ash was subjected to XRD analysis. ppm metal ion in $150 \mathrm{ml}$ plastic bottles placed in a water bath maintained at $25 \pm 0.5{ }^{\circ} \mathrm{C}$. The $\mathrm{pH}$ was adjusted using $0.01 \mathrm{M}$ nitric acid and/or $0.01 \mathrm{M}$ sodium hydroxide. Three samples of $5 \mathrm{ml}$ were collected after five minutes from one bottle at the fifth minute of mixing using a syringe. Thereafter the concentration of metal ions was determined using AAS (Buck, model 210 VGP). All adsorption experiments were carried out in triplicates to check the reproducibility of results. The equilibrium and kinetics data were obtained from batch experiments. The amount of adsorption at equilibrium $\left(\mathrm{q}_{\mathrm{e}}\right)(\mathrm{mg} / \mathrm{g})$ and the percentage adsorption (\%) were computed as follows:

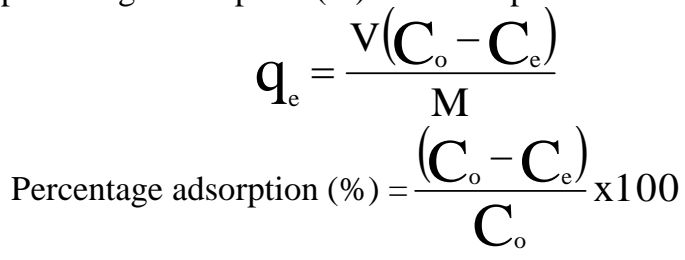

Where, $\mathrm{C}_{\mathrm{o}}$ and are $\mathrm{C}_{\mathrm{e}}$ represented the initial and equilibrium concentrations $(\mathrm{mg} / \mathrm{L}), \quad \mathrm{V}$ is the volume of solution and the $\mathrm{M}$ weight of adsorbent (g).

\subsection{Batch Adsorption Studies}

Batch adsorption equilibrium experiments were conducted for the adsorption of lead and zinc (II) ions on ashed SBE. The effect of contact time, $\mathrm{pH}$, initial metal ion concentration and adsorbent dose were investigated. During the effect of contact time $0.1000 \mathrm{~g}$ of test activated adsorbent was mixed with $100 \mathrm{ml}$ of $10 \mathrm{mg} / \mathrm{L}$ of $\mathrm{Pb}$ (II) or $\mathrm{Zn}$ (II) ions solution. Samples of the mixture were withdrawn after every 5 minutes and filtered. The filtrate was tested for the residual metal ions using AAS (atomic Absorption Spectrometry). 


\section{Results and Discussion}

\subsection{Characterization}

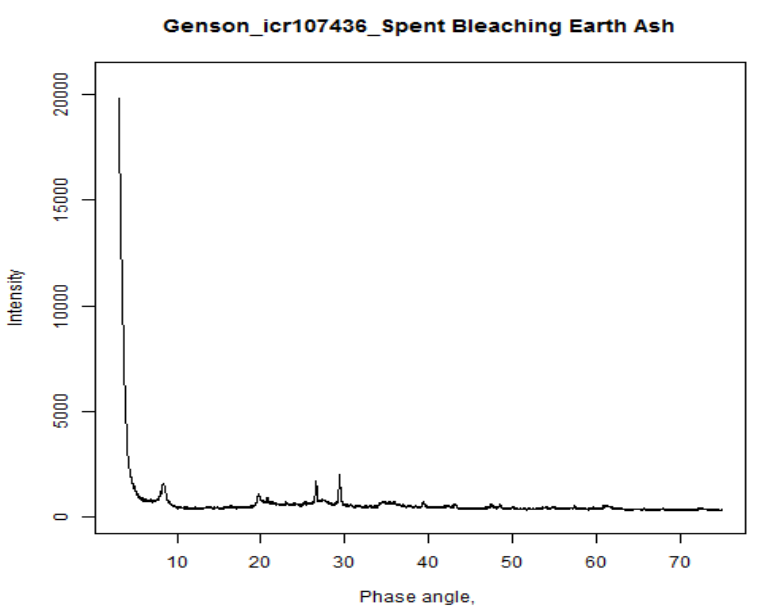

Figure 1: XRD analysis for Ashed SBE

XRD analysis for ashed SBE indicates that it contains $27.6 \%$ 30,4\%, 29.6\%, $12.4 \%$ of Calcite $\left(\mathrm{CaCO}_{3}\right)$, Microcline $\left(\mathrm{KAlSi}_{3}\right)$, Palygorskite $\left.(\mathrm{MgAl})_{2} \mathrm{Si}_{4} \mathrm{O}_{10}(\mathrm{OH}) \cdot 4 \mathrm{H}_{2} \mathrm{O}\right)$, and Quartz $\left(\mathrm{SiO}_{2}\right)$ respectively as the main minerals.

\subsection{Effect of Contact Time}

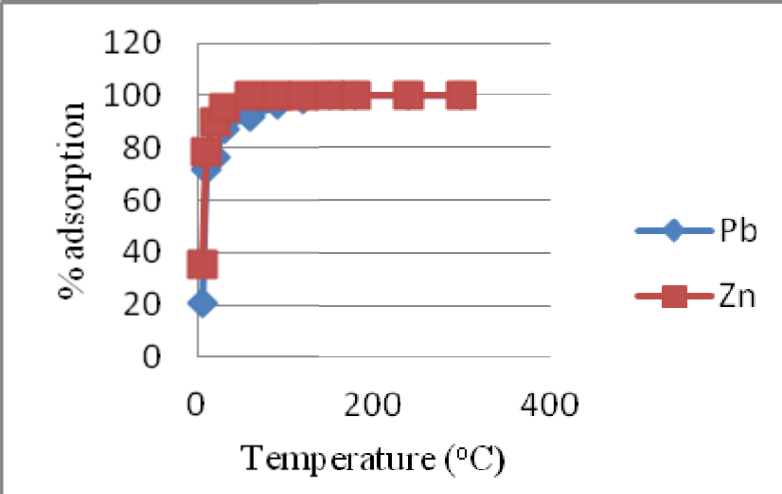

Figure 2: Effect of contact time for adsorption of lead (II) and zinc (II) ions at pH 6.0 and temperature $25 \pm 0.5^{\circ} \mathrm{C}$.

The rate of adsorption is high at the first 30 minutes after which it slows down. [13], observed that at lower initial metal ion concentration the ions interact with the binding sites fully and almost 100 percent adsorption may takes place.

The equilibrium point was reached after 60 and 90 minutes during the adsorption of zinc (II) and Lead (II) ions respectively. [14], found that 60 minutes was sufficient for attaining equilibrium when they studied adsorption of lead (II) ions by activated carbons prepared from marine green algae. They found out that adsorption was rapid and more than $90 \%$ lead (II) ions were adsorbed within the first 30 minutes.

\subsection{Effect of $\mathbf{p H}$}

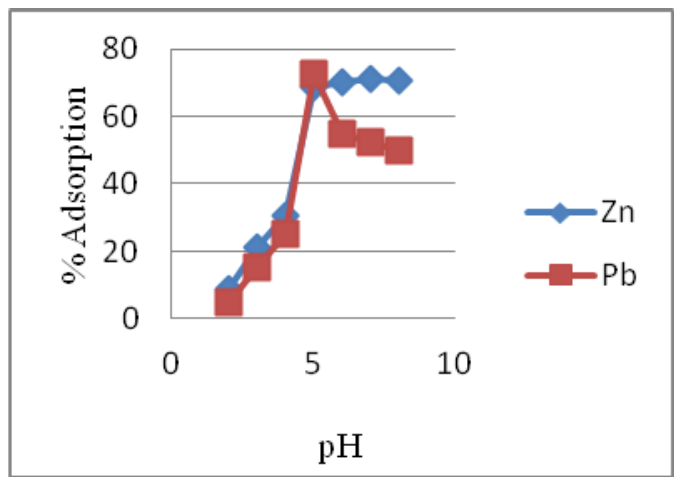

Figure 3: Effect of pH on adsorption of lead (II) and zinc (II) ions at temperature $25 \pm 0.5^{\circ} \mathrm{C}$

The maximum adsorption for lead (II) ions took place at $\mathrm{pH}$ of 5 . Above $\mathrm{pH} 6$ there was decrease in lead (II) ion uptake. [14], observed similar results when they investigated adsorption of lead (II) ions from aqueous solutions using activated carbon from marine algae. They suggested that at $\mathrm{pH}$ less than 2.5, $\mathrm{H}^{+}$ions compete with lead (II) ions for the adsorption sites on surface of the adsorbent. The adsorption of zinc (II) ions continued to increase with the $\mathrm{pH}$. [15], investigating adsorption of zinc (II) ions on kaolinite and metakaolinite, found out that at $\mathrm{pH}$ greater than 6.0 , the solubility of zinc decreased resulting in their precipitation as hydroxide with no significant increase in percentage adsorption. The results show that adsorption of zinc (II) ions onto the adsorbent considered is $\mathrm{pH}$ dependent. The $\mathrm{pH}$ of the solution has a significant impact on the uptake of heavy metals, since it determines the surface charge of the adsorbent, the degree of ionization and the speciation of the adsorbate.

\subsection{Effect of Sorbent Dosage}

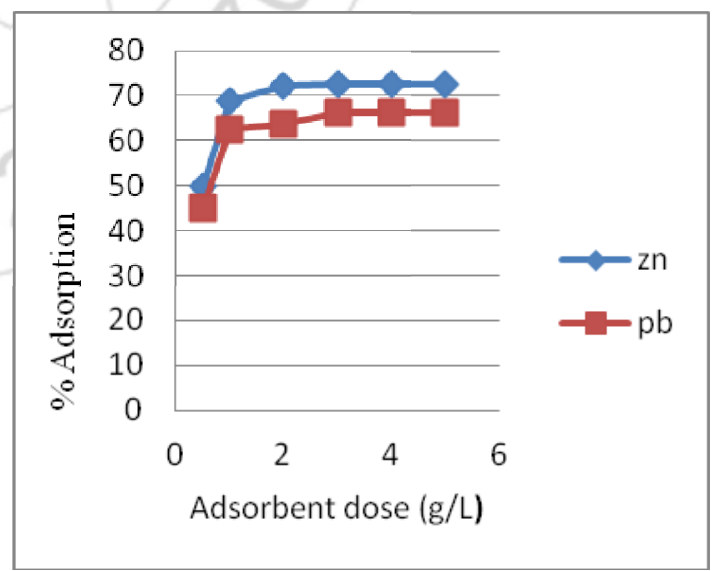

Figure 4: Effect of sorbent dosage on adsorption of lead (II) and zinc (II) ions at initial concentration of $10 \mathrm{mg} / \mathrm{L}, \mathrm{pH} 6.0$ and temperature $25 \pm 0.5^{\circ} \mathrm{C}$.

The results show that there was an increase in the amount of the lead (II) and zinc (II) ions adsorbed According to [16], higher dosage of adsorbent increases the adsorption due to more adsorption sites being available. There was increase in adsorption with the adsorbent dosage was up to a certain amount beyond which further addition of the adsorbent did 


\section{International Journal of Science and Research (IJSR) \\ ISSN (Online): 2319-7064}

Index Copernicus Value (2013): 6.14 | Impact Factor (2014): 5.611

not cause any significant change in the adsorption. [17], suggested that this may due to overlapping of adsorption sites as a result of overcrowding of adsorbent particles. The results show that there was general increase in the amount of zinc (II) ions adsorbed with the increase in adsorbent dosage. [18] in their study on adsorption of copper and zinc from sulfate media on a commercial sorbent also made a similar observation. This result agrees with what [19] found out during their study on adsorption of $\mathrm{Cu}$ (II) ions from regenerated SBE. They suggested that adsorption increased with increasing adsorbent dosage due to increased availability of adsorptive surface. They also found out that although high loading capacities were desirable for sorbent dosages greater than $4 \mathrm{~g} / \mathrm{L}$ the slurry became too thick to agitate effectively. [20], observed that the decline in adsorption beyond certain adsorbent dosages could be due to the aggregation/agglomeration of sorbent particles at higher dosages which would lead to a decrease in the total surface area of the adsorbent particles available to the metal ions.

\subsection{Effect of temperature}

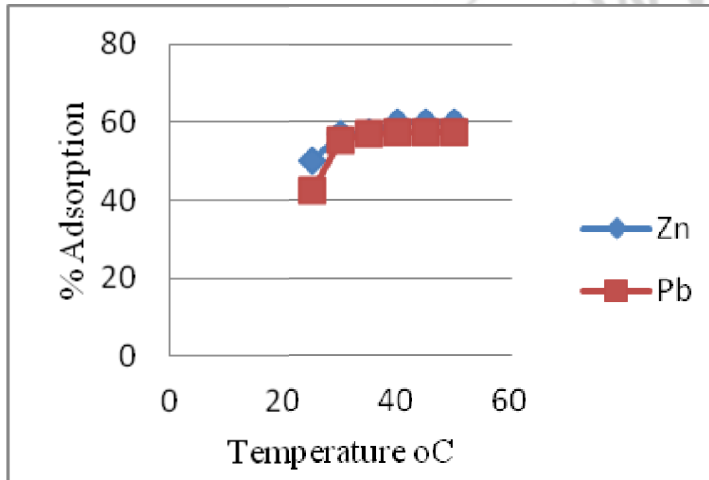

Figure 5: Effect of temperature on adsorption of lead (II) and zinc (II) ions at initial concentration of $10 \mathrm{mg} / \mathrm{L}, \mathrm{pH} 6.0$ and temperature $25 \pm 0.5^{\circ} \mathrm{C}$.

The results show that there was an increase in the amount of the lead (II) and zinc (II) ions adsorbed when, the temperature was increased. [21], in their study on adsorption of Zn (II) ions on Carica papaya root powder obtained similar results. They suggested that the enhancement of the adsorption capacity when temperature is increased could be due to increased mobility and diffusion of ionic species.

\section{6: Effect of Initial Concentration}

An increase in adsorption capacity was realized as the initial concentration was increased. This is because a higher metal concentration means a greater driving force for mass transfer from the aqueous solution to the solid adsorbent. [22], in their study on optimization and kinetic modeling of cadmium desorption from citrus peels observed that the biosorption capacity increases with the increasing metal ion concentration. For a given adsorbent dosage, the amount of metal ion adsorbed per unit area of the adsorbent removal of the metal ions decreased with an increase in the initial concentration. According to [23], the adsorbent has a limit number of active sites, and fewer of them are available at equilibrium sorption at a higher zinc loading levels. The percentage removal however, decreases with increasing metal ion concentration. [24], reported that at higher concentrations, more metal ions are left unabsorbed in solution due to the saturation of binding sites.

\section{6: Adsorption isotherms}

Figures, 6, 7, 8 and 9 show the fits of Langmuir, Freundlich, Temkin and Dubinin-Radushkevich isotherms for adsorption of lead (II) and zinc (II) ions.

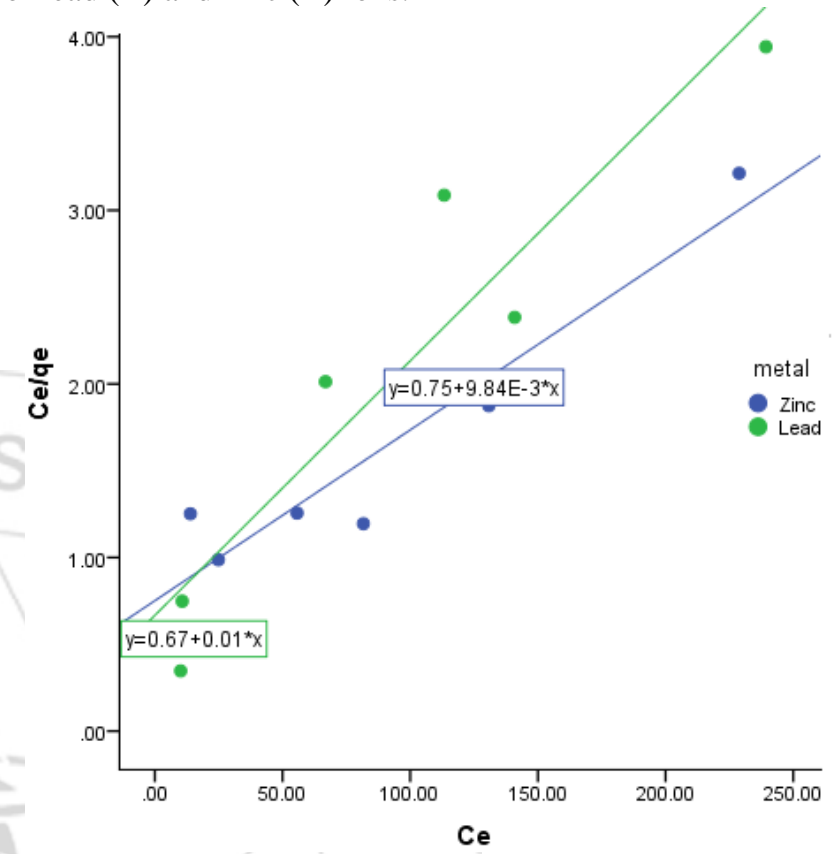

Figure 6: Langmuir biosorption isotherms for adsorption of lead (II) and zinc (II) ions at initial concentration of $10 \mathrm{mg} / \mathrm{L}$, $\mathrm{pH} 6.0$, temperature, $25 \pm 0.5^{\circ} \mathrm{C}$ and adsorbent dose of $2 \mathrm{~g} / \mathrm{L}$.

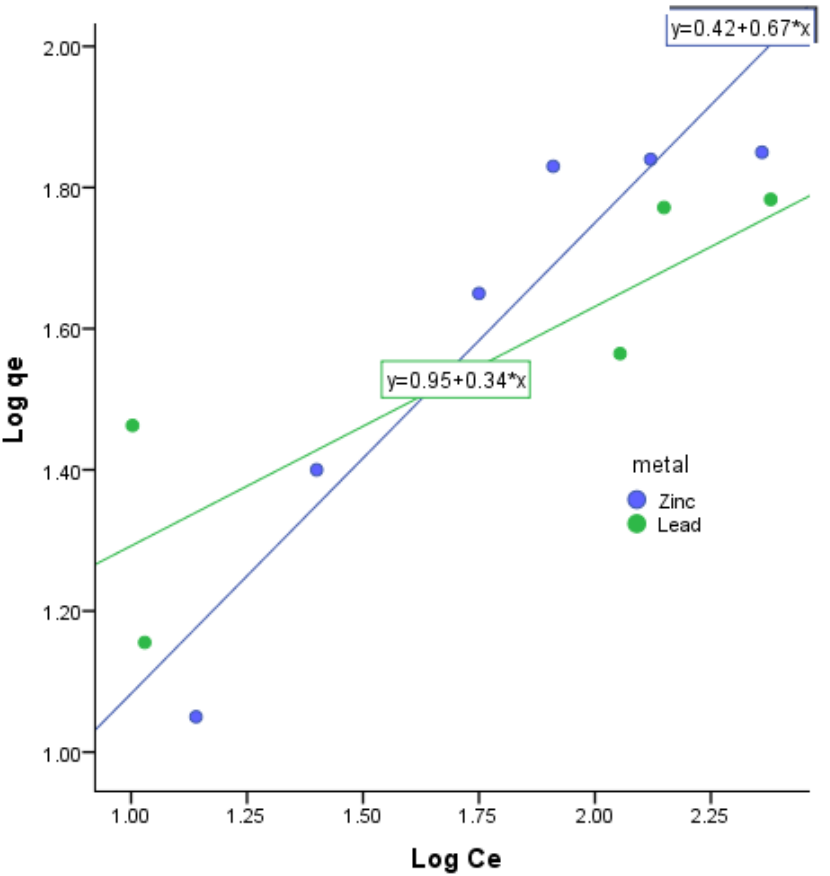

Figure 7: Freundilich adsorption isotherms for adsorption of lead (II) and zinc (II) ions at initial concentration of $10 \mathrm{mg} / \mathrm{L}$, $\mathrm{pH} 6.0$, temperature, $25 \pm 0.5^{\circ} \mathrm{C}$ and adsorbent dose of $2 \mathrm{~g} / \mathrm{L}$. 


\section{International Journal of Science and Research (IJSR) \\ ISSN (Online): 2319-7064}

Index Copernicus Value (2013): 6.14 | Impact Factor (2014): 5.611

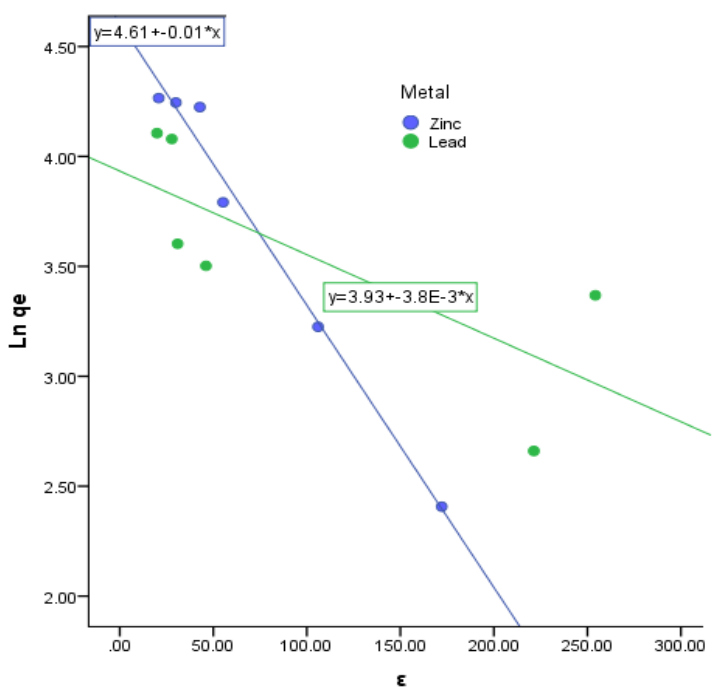

Figure 8: Dubinin-Radushkevich isotherms for adsorption of lead (II) and zinc (II) ions at initial concentration of $10 \mathrm{mg} / \mathrm{L}$, $\mathrm{pH} 6.0$, temperature, $25 \pm 0.5^{\circ} \mathrm{C}$ and adsorbent dose of $2 \mathrm{~g} / \mathrm{L}$.

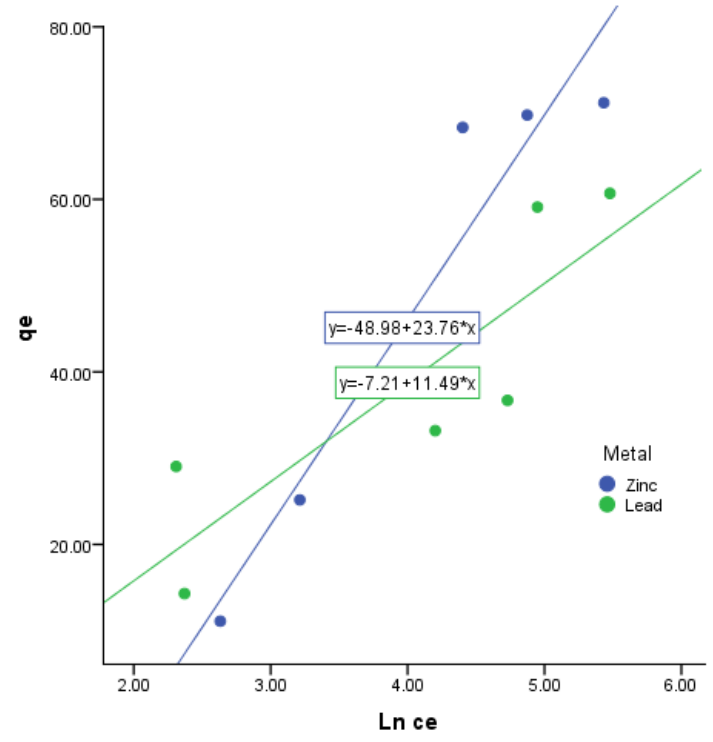

Figure 9: Temkin isotherms for adsorption of lead (II) and zinc (II) ions at initial concentration of $10 \mathrm{mg} / \mathrm{L}, \mathrm{pH} 6.0$, temperature, $25 \pm 0.5^{\circ} \mathrm{C}$ and adsorbent dose of $2 \mathrm{~g} / \mathrm{L}$.

The results indicate that the $\mathrm{R}^{2}$ values for Langmuir fitting for lead (II) and zinc (II) ions adsorption were 1.0 and 0.94 respectively. The $\mathrm{R}^{2}$ values for Freundlich fit for lead (II) and zinc (II) ions were 0.62 and 0.77. Temkin and Dubinin Radushkevich did not exhibit a good fit. These results suggest that Langmuir fits better than Freundlich, Temkin and Dubinin Radushkevich isotherms. According to [25], high $\mathrm{R}^{2}$ for Langmuir adsorption indicates surface homogeneity of the adsorbent and monolayer adsorption. The separation factor $R_{L}$ was found to be between 1 and 10.This suggests that the adsorption is favorable and the material under investigation may be suitable for adsorption.

\section{7: Kinetics of lead (II) and zinc (II) ions adsorption}

Table 1: Parameters of first order Lagergren and Pseudo second order kinetic models.

\begin{tabular}{|c|c|c|c|}
\hline \multicolumn{2}{|c|}{ First order Lagergren } & \multicolumn{2}{c|}{ Pseudo second order } \\
\hline $\mathrm{K}_{\mathrm{L}}$ & $\mathrm{R}^{2}$ & $\mathrm{~K}^{\prime}$ & $\mathrm{R}^{2}$ \\
\hline 0.060 & 0.8973 & 1.21 & 0.9995 \\
\hline
\end{tabular}

The linear regression $\mathrm{R}^{2}$ show that pseudo second order gave a better fit than first order lagergren. According to [26] the metal-biosorbent reactions may be the rate limiting step. They explained that some adsorption sites become more difficult to reach due to their position in deeper pores. The adsorption of the metal ions increases sharply at the beginning of the process followed by a slower uptake as the equilibrium is approached. [27], made a similar observation when they assessed metal sorption by the marine algae. According to [2], the rate of removal of the two ions is higher in the beginning probably due to a larger surface area of the adsorbent available.

\section{Conclusions}

The results of this work indicate that ASBE is a promising material for sequestering heavy metal from industrial effluents. The adsorption data fitted the Langmiur model and the maximum adsorption capacities were found to be 43.4 and $29.79 \mathrm{q}_{\max } \mathrm{Mg} / \mathrm{g}$ during adsorption of lead (II) and zinc (II) ions respectively at $25 \pm 0.5^{\circ} \mathrm{C}$. Kinetic analyses showed that the adsorption followed a pseudo second order.

\section{Acknowledgements}

The authors of this work would like to thank ICRAF, Kenyatta University ICRAF, Geology and mines and Jomo Kenyatta university of Agriculture and Technology for the technical support in their laboratories.

\section{References}

[1] Jalali R, Ghafourian H, Asef Y, Davarpanah SJ, Sepehr S (2002) Removal andrecovery of lead using non-living biomass of marine algae. J Hazard Mater 92:253-262

[2] Jeyakumar .,S and Chandrasekaran ,2014) Adsorption of lead(II) ions by activated carbons prepared from marine green algae: Equilibrium International Journal of Industrial Chemistry, 5 (2), 2-10

[3] Nancy, M.H., William, R.M., and John, C. (2009). Determination of Total Lead in Lipstick: Development and Validation of a Microwave-Assisted Digestion, Inductively Coupled Plasma-Mass Spectrometric Method. journal of cosmetic science 60, 405-414.

[4] Ciubotariu, D., Ghiciuc, C.M., and Lupuşoru, C.E. (2015). Zinc Involvement in Opioid Addiction and Analgesia - Should Zinc Supplementation be Recommended for Opioid-Treated Persons? Substance Abuse Treatment, Prevention, and Policy 10, 29.

[5] Gakwisiri, C., Raut, N., Al-Saadi, A., Al-Aisri, A., and Al-Ajmi, A. (2012). A Critical Review of Removal of 


\section{International Journal of Science and Research (IJSR) \\ ISSN (Online): 2319-7064}

Index Copernicus Value (2013): 6.14 | Impact Factor (2014): 5.611

Zinc from Wastewater. Proceedings of the World Congress on Engineering 1, 627-630.

[6] Panida, S., Pisit, C., and Xianshe, F. (2014). Equilibrium Isotherm Models for Adsorption of Zinc (II) ion from Aqueous Solution on Pulp Waste. Advanced materials research 931, 215-219.

[7] Dada, A.O., Olalekan, A.P., Olatunya, A.M., and DADA, O. (2012). Langmuir, Freundlich, Temkin and Dubinin-Radushkevich Isotherms Studies of Equilibrium Sorption of Zn2+ Unto Phosphoric Acid Modified Rice Husk. Journal of Applied Chemistry 3, 38-45.

[8] Awwad, A.M., and Salem, N.M. (2012). Biosorption of Copper (II) and Lead (II) ions from aqueous solution by Modified Loquat (Erioyobotra japonica) Leaves,. Biosorption of copper (II) and lead (II) ions from aqueous solution by modified loquat (Erioyobotra japonica) leaves, 2012, 3.

[9] Slimani, R., Anouzla, A., Abrouki, Y., Ramli, Y., Antri EL, S., Mamouni, R., and Lazar, S. (2011). Removal of a Cationic Dye -Methylene Blue- from Aqueous Media by the Use of Animal Bone Meal as a New Low Cost Adsorbent,. Journal of Materials and Environmental Science 2, 77-87.

[10] Edwin, A.O., Olawale, D.W., Kennet, K.A., and Ayodeji, O.A. (2013). Assessment of Langmuir, Freundlich and Dubinin- Radushkevich Adsorption Isotherms for the Biosorption of $\mathrm{Mn}(\mathrm{II})$ Ions From Aqueous Solution by Untreated and Acid-Treated Corn Shaft. International Journal of Scientific \& Engineering Research, 4, 1629-1639.

[11]Baybars, A.F., Recep, B., Alper, E.Y., and Salkan, B. (2012). Adsorption Kinetics and Isotherms for the Removal of Zinc Ions from Aqueous Solutions by an Ion-Exchange Resin. journal of the chemical society of Pakistan 34, 842.

[12] İsmail, Ö., Utkan, Ö., Bilge, Ö., and Veli, S. (2013). Kinetic, thermodynamic, and equilibrium studies for adsorption of azo reactive dye onto a novel waste adsorbent: charcoal ash. Desalination and Water Treatment, 51, 6091-6100.

[13] Ashraf, M., and Essa, M. (2012). The Effect of a Continuous Mercury Stress on Mercury Reducing Community of Some Characterized Bacterial Strains. African Journal of Microbiology Research 6, 4006-4012.

[14] Jeykumar, S., and Chandra, S. (2015). Adsorption of Lead(II) Ions by Activated Carbons Prepared from Marine Green Algae: Equilibrium and Kinetics Studies. International Journal of Industrial Chemistry, 5, 1-10.

[15] Ndi Nsami, J., Ndongo, G., Kounou, D.P., Belibi, B., Kouoto , D., UTagne, G., M., , Dina Joh, D.D., and J., K.M. (2015). Adsorption of Zinc (II) Ions from Aqueous Solution onto Kaolinite and Metakaolinite. Der Pharma Chemica 7, 51-58

[16] Davila- Jimenez, M.M., Elizalde- Gonzalez, M.P., Geyer, W., Mattusch, J., and Winnerich, R. (2003). Adsorption of Metal Cations From Aqueous Solutions Onto a Natural and a Model Bicomposite. Colloids Surfaces A: Physicochem Engineering Aspects 219, 243.

[17] Tumin, N.D., Chuah, A.L., Zawani, Z., and Rashid, S.A. (2008). Adsorption of Copper from Aqueous Solution by
Elaisguineensis Kernel Activated Carbon. Journal of Engineering Science and Technology 3, 180-189.

[18] Morcali, M.H., Zeytuncu, B., Baysal, A., Akman, S., and Yucel, O. (2014). Adsorption of Copper and Zinc from Sulfate Media on a Commercial Sorbent. Journal of Chemical Engineering 2, 1655-1652.

[19] Wambu, E.W., Muthakia, G.K., Wa -Thiong'o, J.K., and Shiundu, P.M. (2006). Regeneration of Spent Bleaching Earth and its Adsorption of $\mathrm{Cu}$ (II) Ions from Solutions. Applied clay science 46, 176-180.

[20] Chigondo, F., Nyamunda, B.C., Sithole, S.C., and Gwatidzo, L. (2013). Removal of Lead (II) and Copper (II) Ions From Aqueous Solution by Baobab Adononsia Digitata Fruit Shells Biomass,. IOSR Journal of Applied Chemistry 5, 43-50.

[21] Alao, O., Ajaelu, C., and Ayeni, O.J. (2014). Kinetics, Equilibrium and Thermodynamic Studies of the Adsorption of Zinc (II) ions on Carica Papaya Root Powder. Research Journal of Chemical Sciences 4, 3238.

[22] Njikam, E., and Scheiwer, S. (2012). Optimization and Kinetic Modeling of Cadmium Desorption from Citrus Peels; aProcess for Biosorbent Regeneration. Journal of Hazardous Materials 213, 242-248.

[23]Witek, K., Harikishore, A., and Kumar, R. (2013). Removal of Micro Elemental Cr (III) and Cu(II) by Using Soyabean Meal Waste- Unusual Isotherms and Insights of Binding Mechanism. Bioresource technology 127, 350-357.

[24] Ahalya, N., and Ramachandra, T.V. (2003). Biosorption of heavy metals. Research Journal of Chemistry and Environment 7, 1-5.

[25] Herrero, R., Lodeiro, P., Rojo, R., Ciorba, A., Rodriguez, P., and Sastre de Vicente, M.E. (2008). The Efficiency of the Red Alga Mastocarpus Stellatus for Remediation of Cadmium Pollution. Bioresource Technology 99, 4138.

[26] Hubble,M.A., Beck, K.R., O’Neal, W.G and Sharma, Y.C. (2012). Celluiosic substrates for removal ofpollutants from aqueous systems: A review.2.Dyes, Bioresources 7(2), 2592-2687.

[27] Neide, E.V., Carrilho, M., and Gilbert, R.T. (2000). Assessing Metal Sorption of Marine Algae Journal environment monitoring 2, 410. 